Bangl. J. Vet. Med. (2010). 8(2): 97 - 106

\title{
DETERMINATION OF SENSITIVITY AND SPECIFICITY OF IN-HOUSE SANDWICH ELISA FOR THE DETECTION OF INFECTIOUS BURSAL DISEASE VIRUSES
}

\author{
P K Saha ${ }^{1}$, M H Ali ${ }^{1}$, M B Rahman ${ }^{1}$ and M A Islam ${ }^{1,2}$ \\ ${ }^{1}$ Department of Microbiology and Hygiene, Faculty of Veterinary Science, Bangladesh Agricultural University, \\ Mymensingh-2202 and ${ }^{2}$ School of Sustainable Agriculture, University Malaysia Sabah, 88999, \\ Kota Kinabalu, Sabah, Malaysia
}

\begin{abstract}
The study was designed for the development of an In-House sandwich ELISA as a suitable serological method for the rapid detection of infectious bursal disease virus (IBDV). The test was also designed to compare and evaluate its sensitivity and specificity with other traditional methods used for the detection of IBDV from field outbreak cases prevalent among the poultry population of Bangladesh. To develop the In-House sandwich ELISA, hyper-immune serum was raised against live IBDV vaccine in rabbit which was used to coat each of the 96-well flat bottomed polystyrene microtitre plate whereas, hyperimmune sera raised in chickens against IBDV used as secondary antibody. The newly developed In-House sandwich ELISA was standardized by dispensing different dilutions $\left(10^{-1}\right.$ up to $\left.10^{-4}\right)$ of rabbit serum. Among them, the $10^{-2}$ dilution of serum showed most suitable reading for the detection of IBD virus and used to coat the plate to evaluate its sensitivity and specificity. Sensitivity test was done by different dilutions $\left(10^{-0}\right.$ to $\left.10^{-4}\right)$ of reference IBD virus. The virus dilution, $10^{-3}$ was the highest dilution having lowest capacity to bind with coated antibody of the ELISA plate which indicated that IBD viruses was absent in the dilutions of above $10^{-3}$. The cut-off value of negative control samples was determined as 0.937 which indicated titer of tested samples $>0.937$ was positive and $<0.937$ was negative. Specificity test was performed using different known viruses (IBDV and NDV) using different dilutions $\left(10^{-1}\right.$ up to $\left.10^{-4}\right)$. Only the IBDV showed positive result which indicated high specificity of newly developed ELISA plate. A total of 26 samples (feces, cloacal swab, spleen and bursa) from control group, experimental and natural IBDV outbreaks were used as field viral antigen for the evaluation of sensitivity and specificity of the newly developed In-House sandwich ELISA. In case of experimental infection, 5 (62.5\%) of 8 feces sample but none of cloacal swab were positive for IBDV whereas, all bursa and spleen samples were positive by both In-House sandwich ELISA and AGIDT. In case of natural outbreak cases, 6 of 6 bursal samples and 4 of 6 spleen samples were positive by In-House sandwich ELISA whereas, AGIDT detected all bursal and 3 spleen samples. No virus was detected from the samples of control group. The result showed 92.85\% specificity of the developed sandwich ELISA for detection of IBDV with AGIDT which indicated that the developed ELISA is a sensitive, specific, cost effective and reliable tool for the detection of IBDV antigen from a large number of field samples.
\end{abstract}

Key words: IBDV, sandwich ELISA, AGIDT

\section{INTRODUCTION}

Infectious bursal disease (IBD) also known as Gumboro disease, is one of the highly contagious viral diseases of young chickens caused by infectious bursal disease virus (IBDV) belongs to the genus Avibirnavirus of the family Birnaviridae having bi-segmented dsRNA genome (Jackwood et al., 1984). The disease is characterized by immunosuppression, depression, debilitation, dehydration and high mortality generally at 3 to 6 weeks of age. The disease is economically important to the poultry industry worldwide due to increased susceptibility to other diseases and negative interference with effective vaccination. In recent years, very virulent strains of IBDV (vvIBDV) causing high mortality in chicken have emerged in South-East Asia, Europe, Latin America, Africa, and the Middle East. There are two distinct sero-types of the virus (McFerren et al., 1980), but only sero-type 1 virus causes disease in poultry and includes the classical virulent (cv), very virulent (vv) and variant strains (Van den Berg et al., 1991). At least six antigenic sub-types of IBDV serotype 1 have been identified by in-vitro crossneutralization assay. Viruses belonging to one of these antigenic sub-types are commonly known as variants, which were reported to break through high levels of maternal derived antibodies in commercial flocks, causing up to 60 to 100 percent mortality in chickens.

*Corresponding author: e-mail: alim_bau@yahoo.co.in

Copyright $(2010$ Bangladesh Society for Veterinary Medicine All rights reserved 1729-7893/0207/10 


\section{P K Saha and others}

When any outbreaks occur in a farm, initiatives are taken to confirm the diagnosis and measures are taken accordingly to reduce morbidity and mortality to prevent further spread of causal agent. So, it is necessary to diagnose the disease quickly and perfectly. In our country, clinical signs and post mortem lesions are commonly used as the main basis for the diagnosis of IBD. Though gross lesions found in IBD affected poultry is considered sufficient for diagnosis of IBD (Cosgrove, 1962), but the clinical signs, post mortem lesions and histopathological findings of IBD are very much similar with other bacterial and viral diseases of poultry (Banda, 2002). Various serological tests like agar gel immunodiffusion test (AGIDT) (Patnayak et al., 1997), serum neutralization test (SNT), indirect hemagglutination (IHA) test, enzyme-linked immunosorbent assay and molecular test like RT-PCR are employed for confirmatory diagnosis of the disease (Liu et al., 1998). The enzyme-linked immunosorbent assay (ELISA) is commonly used as a rapid and sensitive test for detection of IBDV antigen or antibody against IBDV (Marquardt et al., 1980; Howie and Thorson, 1981 and Solano et al., 1985). ELISA is now being used for sero-profiling of chicken flocks and examination of the efficiency of vaccines (Solano et al., 1986). Studies of the molecular epidemiology of IBDV are important, and the DASELISA could be an alternative technique for screening a large number of samples before testing (Tham et al., 1995).

This paper describes the development of an In-House sandwich ELISA for rapid detection of IBDV antigens from large number of field samples and comparison of sensitivitiy with the agar gel immunodiffusion test (AGIDT) in detecting IBDV antigen using field and laboratory samples.

\section{MATERIALS AND METHODS}

Rabbit anti-IBDV reference serum: The New Zealand white rabbits $(n=4)$ were vaccinated with live IBD vaccine (BAL-IBD EM from BESTAR) on day 7, 14 and 21 through S/C route @ $0.5 \mathrm{ml} / \mathrm{rabbit}$ and blood was collected prior to first and during each vaccination. The separated serum was checked with reference IBD virus by AGIDT for IBDV antibodies and positive sera were used as coating antibody and positive control. The serum collected from one non-vaccinated control rabbit was screened for the antibodies against IBDV and used as negative control.

Chicken anti-IBDV serum: ISA Brown chickens $(n=4)$ of two months old were vaccinated followed by blood collection thrice at day 7, 14 and 21 with live IBDV vaccine through ocular route. The separated sera samples were checked for anti-IBDV antibodies by AGIDT against reference IBDV antigen and positive sera were pooled to use as secondary antibody and positive control. For negative control serum blood was collected at day 28 from two non-vaccinated birds and checked by AGIDT to confirm the absence of antibody. All the sera samples were preserved at $-20^{\circ} \mathrm{C}$ in the screw-capped vial until used.

Reference IBD virus: Virulent strain of IBDV was used as reference virus obtained from the Department of Microbiology and Hygiene, Bangladesh Agricultural University, Mymensingh.

Detection of anti-IBDV antibody and IBDV antigen by agar gel immunodiffusion test (AGIDT)

All the sera samples raised in rabbit and chicken using live IBDV vaccine and prepared antigen from the samples of experimental and natural IBD outbreak cases were tested using known IBDV antigen and raised hyperimmune serum in chicken against IBDV vaccine respectively. The test was performed following the procedures described by Wyeth (2000).

\section{Coating of the microtitre plate with hyper-immune serum raised in rabbit against IBDV}

For the development of an In-House sandwich ELISA, flat bottomed 96-well microtitre plates were used (Tanimura et al., 1995). A $100 \mu \mathrm{l}$ of hyper-immune serum of each dilution $\left(10^{-1}\right.$ to $\left.10^{-4}\right)$ with coating buffer (pH 9.6) were dispensed on each well of microtitre plate (each dilution for two rows) and incubated at $37^{\circ} \mathrm{C}$ for $1 \mathrm{~h}$, followed by overnight at $4^{0} \mathrm{C}$. A $100 \mu \mathrm{l}$ of block ace solution (4\% BSA) was added to each well and incubated at $37^{\circ} \mathrm{C}$ for $1 \mathrm{~h}$ to block unbinding sites. Then the plate was emptied and washed 3 times with $200 \mu \mathrm{l}$ of washing buffer $\left(0.5 \%\right.$ Tween $_{20}$ in PBS) and the antibody coated plate was stored at $-20^{\circ} \mathrm{C}$ until use. A $20 \%$ bursal suspension was prepared from the sample of naturally and experimentally infected birds and used as a source of viral antigen for In-House sandwich ELISA. 
Standardization of optimal concentration of hyper-immune serum to coat the newly developed In-House sandwich ELISA plate

A $100 \mu \mathrm{l}$ of each diluted $\left(10^{0}\right.$ to $\left.10^{-3}\right)$ known IBDV antigen were dispensed on A \& B, C \& D, E \& F as well as G $\& \mathrm{H}$ rows respectively up-to 10 number well of microtitre plate (11 was negative control and 12 positive control) of newly developed In-House sandwich ELISA plate and incubated at $37^{\circ} \mathrm{C}$ for 1 hour. Excess antigen was removed and washed with PBST $_{20}$. A $100 \mu$ l of sera raised in chickens $\left(10^{0}, 10^{-1}\right.$ to $\left.10^{-3}\right)$ were dispensed on all wells A \& B, C \& D, E \& F as well as G \& H respectively and incubated at $37^{\circ} \mathrm{C}$ for $1 \mathrm{~h}$. Excess antibody was removed and washed with $\mathrm{PBST}_{20}$. A $100 \mu \mathrm{l}$ of conjugate solution was added in each well and incubated for $1 \mathrm{~h}$ at $37^{\circ} \mathrm{C}$ followed by emptying and washing of the plate. Then, $100 \mu \mathrm{l}$ of substrate solution (OPD) was added and incubated for 30 minute at room temperature. Orange color was developed in case of positive reaction and the reaction was stopped by adding $100 \mu \mathrm{l}$ of stop solution $\left(1 \mathrm{~N} \mathrm{H}_{2} \mathrm{SO}_{4}\right)$. The OD (optical density) value was determined using an ELISA reader at $405 \mathrm{~nm}$ filter.

\section{Coating of microtitre plate with hyper-immune sera at $10^{-2}$ dilution to develop an In-House sandwich ELISA}

A $100 \mu \mathrm{l}$ of diluted $\left(10^{-2}\right)$ anti-IBDV rabbit hyper-immune sera were dispensed on each of the 96-wells flat bottomed microtitre plate and incubated at $37^{0} \mathrm{C}$ for 1 hour, followed by overnight incubation at $4^{0} \mathrm{C}$. A $100 \mu \mathrm{l}$ of block ace solution was added to each well and incubated at $37^{\circ} \mathrm{C}$ for 1 hour. Excess blocking solution was discarded and the plate was washed 5 times with $\mathrm{PBST}_{20}$. Finally the antibody coated plate was stored at $4^{0} \mathrm{C}$ until use.

\section{Standardization of sensitivity of the In-House sandwich ELISA}

A $100 \mu \mathrm{l}$ of reference IBDV antigen $\left(10^{-1}\right.$ to $\left.10^{-4}\right)$ were added into the wells of A \& B, C \& D, E \& F, as well as $\mathrm{G} \& \mathrm{H}$ rows of previously coated plate with $10^{-2}$ diluted rabbit hyper-immune serum and incubated at $37^{0} \mathrm{C}$ for 1 h. Excess antigen was removed and the plate was washed. A $100 \mu \mathrm{l}$ of $10^{-2}$ diluted sera raised in chickens were dispensed on each well except column 11 (negative control) and 12 (positive control) and incubated at $37^{\circ} \mathrm{C}$ for 1 h. Excess antibody was removed and washed with $\mathrm{PBST}_{20}$. A $100 \mu \mathrm{l}$ of conjugate solution was added and incubated at $37^{\circ} \mathrm{C}$ for $1 \mathrm{~h}$ followed by emptying and washing of the plate. Then, $100 \mu \mathrm{l}$ of substrate was added and incubated for 30 minutes at room temperature. The reaction was stopped by adding $100 \mu$ of stop solution $\left(1 \mathrm{~N} \mathrm{H}_{2} \mathrm{SO}_{4}\right)$ and $\mathrm{OD}$ value was determined using an ELISA reader at $405 \mathrm{~nm}$ filter.

\section{Standardization of specificity of the newly developed In-House sandwich ELISA}

The specificity test of the plate coated with anti-IBDV serum $\left(10^{-2}\right)$ was performed using known IBDV and NDV antigens. A $100 \mu \mathrm{l}$ of each antigen $\left(10^{-1}, 10^{-2}, 10^{-3}\right.$ and $\left.10^{-4}\right)$ were dispensed on all wells of the plate except $11^{\text {th }}$ (Negative control) and $12^{\text {th }}$ (positive control) column and incubated at $37^{0} \mathrm{C}$ for $1 \mathrm{~h}$. Excess antigen was removed and the plate was washed 5 times with $\mathrm{PBST}_{20}$. A $100 \mu \mathrm{l}$ of undiluted $\left(10^{0}\right)$ and diluted $\left(10^{-1}, 10^{-2}, 10^{-3}\right)$ secondary antibody were dispensed on all wells except column $11 \& 12$ and incubated at $37^{0} \mathrm{C}$ for $1 \mathrm{~h}$. Excess antibody was removed and washed with $\mathrm{PBST}_{20}$. A $100 \mu \mathrm{l}$ of conjugate was added and incubated at $37^{\circ} \mathrm{C}$ for $1 \mathrm{~h}$ followed by emptying and washing of the plate. Then, $100 \mu \mathrm{l}$ of substrate was added and incubated for 30 minutes at room temperature. The reaction was stopped by adding $100 \mu \mathrm{l}$ of stop solution and OD value was determined using an ELISA reader at $405 \mathrm{~nm}$ filter.

\section{Evaluation of sensitivity and specificity of In-House sandwich ELISA}

Three, 25-day-old local chickens were bought from KR market, BAU Mymensingh for experimental infection. Various samples (8 feces, 8 cloacal swab, 2 spleen and 2bursa) from experimentally infected and natural outbreaks cases (6 bursa and 6 spleens) from three layer farms (Mymensingh, Muktagacha and Sirajgonj) were subjected to prepare $20 \%$ inoculums with PBS to evaluate the newly developed ELISA. A $100 \mu$ l of undiluted $\left(10^{0}\right)$ inocula were dispensed into all wells of the rows A to $\mathrm{H}$ respectively coated with anti-IBDV antibody $\left(10^{-2}\right)$ and incubated at $37^{\circ} \mathrm{C}$ for $1 \mathrm{~h}$. Excess antigen was removed and the plate was washed with $\mathrm{PBST}_{20}$. Addition of $100 \mu \mathrm{l}$ sera raised in chickens $\left(10^{0}, 10^{-1}\right.$ to $\left.10^{-3}\right)$ on A to $\mathrm{H}$ rows respectively and incubated at $37^{0} \mathrm{C}$ for $1 \mathrm{~h}$. Excess antibody was removed and washed with $\mathrm{PBST}_{20}$. A $100 \mu \mathrm{l}$ of conjugate was added to all wells and incubated at $37^{\circ} \mathrm{C}$ for $1 \mathrm{~h}$ followed by emptying and washing. Then, $100 \mu \mathrm{l}$ of substrate was added and incubated for 30 minutes at room temperature. Orange color was developed in case of positive reaction and the reaction stopped by adding $100 \mu \mathrm{l}$ of stop solution $\left(1 \mathrm{~N} \mathrm{H}_{2} \mathrm{SO}_{4}\right)$. The OD value was determined using an ELISA reader at $405 \mathrm{~nm}$ filter. 


\section{P K Saha and others}

\section{Statistical Analysis}

The statistical analysis to compare the specificity between the newly developed In-House sandwich ELISA and agar gel immunodiffusion tests was done according to the statistical formula given by Samad et al. (1994). The statistical formula was used as described below.

\begin{tabular}{l|l|c|c|c}
\hline \multicolumn{2}{l}{} & \multicolumn{2}{c|}{$\begin{array}{c}\text { Gold standard test (agar gel } \\
\text { immunodiffusion test) }\end{array}$} & Total \\
\cline { 3 - 5 } \multicolumn{2}{l|}{} & Positive & Negative & \\
\hline \multirow{2}{*}{$\begin{array}{l}\text { In-House sandwich } \\
\text { ELISA }\end{array}$} & Positive & $\mathrm{a}$ & $\mathrm{b}$ & $\mathrm{a}+\mathrm{b}$ \\
\cline { 2 - 5 } & Negative & $\mathrm{c}$ & $\mathrm{d}$ & $\mathrm{c}+\mathrm{d}$ \\
\hline \multicolumn{2}{l|l}{ Total } & $\mathrm{a}+\mathrm{c}$ & $\mathrm{b}+\mathrm{d}$ & $\mathrm{a}+\mathrm{b}+\mathrm{c}+\mathrm{d}=\mathrm{N}$ \\
\hline
\end{tabular}

The notations used above are defined as under.

$\mathrm{a}=$ Number of samples positive to both conventional and the gold standard tests

$\mathrm{b}=$ Number of samples positive to conventional but negative to the gold standard test

$c=$ Number of samples negative to conventional but positive to the gold standard test

$\mathrm{d}=$ Number of samples negative to both conventional and the gold standard tests

$\mathrm{a}+\mathrm{b}+\mathrm{c}+\mathrm{d}=$ Total number of samples $(\mathrm{N})$

Specificity: It is the capacity of the test to detect non-diseased cases, when compared with the gold standard test $(d / b+d x 100)$.

\section{RESULTS AND DISCUSSION}

\section{Confirmation of anti-IBDV antibody raised in rabbit and chicken by AGIDT}

Prominent white line of precipitation was formed between bursal homogenates of the central well and known positive anti-IBDV hyper-immune serum of each of the five of the six peripheral wells due to antigen and antibody reaction. The band was more distinct incase of the serum collected after $28^{\text {th }}$ days of vaccination than the others. Similar findings were reported by Joshi and Shakya (1996), Thevathasan and Jayawardana (1997), Umapathi et al. (2002) and Makadiya (2004).

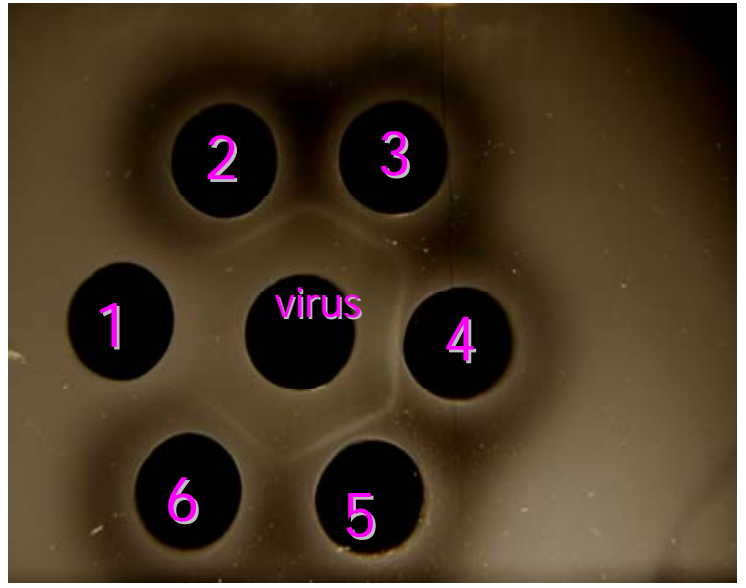

Plate 4: AGIDT slide showing positive result for the prepared hyper immune serum of rabbit against IBDV Well $1=$ Control serum, 2\&6= Serum before $1^{\text {s }}$ vaccination, $3=$ Serum after day 7 of $1^{\text {st }}$ vaccination, $4=$ Serum after day 7 of $2^{\text {nd }}$ vaccination, $5=$ Serum after day 7 of $3^{\text {rd }}$ vaccination.

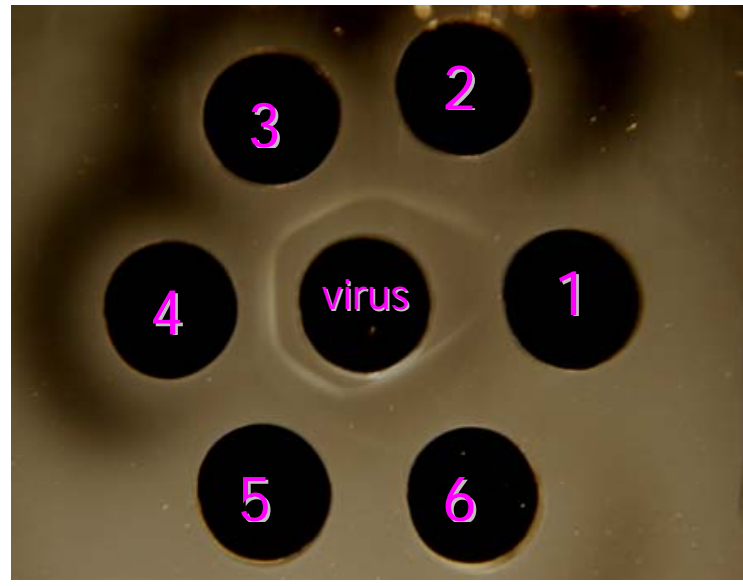

Plate 5: AGIDT slide showing positive result for the prepared hyper immune serum of chicken against IBDV. $1=$ Control serum, $2 \& 6=$ Serum before $1^{\text {st }}$ vaccination, $3=$ Serum after day 7 of $1^{\text {st }}$ vaccination, $4=$ Serum after 7 day of $2^{\text {nd }}$ vaccination, $5=$ Serum after 7 day of $3^{\text {rd }}$ vaccination. 
Determination of sensitivity and specificity of in-house sandwich ELISA

Standardization of optimal concentration of hyper-immune serum to coat the newly developed In-House sandwich ELISA plate

Among various dilutions $\left(10^{-1}\right.$ up to $\left.10^{-4}\right)$ of hyper-immune serum raised in rabbit, the serum dilution $10^{-2}$ showed suitable reading for the detection of IBD virus. For this reason, the developed sandwich ELISA was further coated with $10^{-2}$ dilution of hyper-immune serum to evaluate the sensitivity and specificity of the newly developed In-House sandwich ELISA (Table 1).

Table 1. OD values for the standardization of newly developed in-House sandwich ELISA

\begin{tabular}{|c|c|c|c|c|c|c|c|c|c|c|c|c|c|c|}
\hline & \multirow{2}{*}{$\begin{array}{l}\text { Hyper- } \\
\text { immune } \\
\text { serum } \\
\text { dilution to } \\
\text { coat the } \\
\text { plate }\end{array}$} & \multirow{2}{*}{$\begin{array}{c}\text { Dilution } \\
\text { of } \\
\text { known } \\
\text { IBD } \\
\text { virus }\end{array}$} & \multicolumn{12}{|c|}{ OD value of sandwich ELISA } \\
\hline & & & 1 & 2 & 3 & 4 & 5 & 6 & 7 & 8 & 9 & 10 & $11^{*}$ & $12^{* *}$ \\
\hline A & $10^{-1}$ & $10^{0}$ & 2.814 & 2.879 & 2.868 & 2.807 & 2.763 & 2.707 & 2.789 & 2.677 & 2.683 & 2.715 & 0.639 & 1.976 \\
\hline $\mathrm{B}$ & $10^{-1}$ & $10^{\circ}$ & 2.868 & 2.838 & 2.829 & 2.820 & 2.778 & 2.869 & 2.650 & 2.757 & 2.657 & 2.747 & 0.568 & 2.189 \\
\hline $\mathrm{C}$ & $10^{-2}$ & $10^{-1}$ & 2.667 & 2.646 & 2.637 & 2.677 & 2.631 & 2.569 & 2.595 & 2.568 & 2.693 & 2.664 & 0.624 & 2.213 \\
\hline $\mathrm{D}$ & $10^{-2}$ & $10^{-1}$ & 2.650 & 2.621 & 2.676 & 2.668 & 2.706 & 2.658 & 2.694 & 2.689 & 2.635 & 2.598 & 0.695 & 2.234 \\
\hline $\mathrm{E}$ & $10^{-3}$ & $10^{-2}$ & 1.854 & 1.971 & 2.014 & 1.962 & 1.864 & 1.924 & 2.015 & 1.675 & 2.139 & 1.629 & 0.761 & 2.378 \\
\hline $\mathrm{F}$ & $10^{-3}$ & $10^{-2}$ & 1.964 & 2.202 & 1.958 & 1.729 & 1.857 & 2.034 & 1.824 & 1.546 & 1.964 & 1.846 & 0.772 & 2.563 \\
\hline $\mathrm{G}$ & $10^{-4}$ & $10^{-3}$ & 1.686 & 1.490 & 1.486 & 1.481 & 1.476 & 1.675 & 1.428 & 1.414 & 1.356 & 1.426 & 0.786 & 2.265 \\
\hline $\mathrm{H}$ & $10^{-4}$ & $10^{-3}$ & 1.468 & 1.465 & 1.446 & 1.437 & 1.430 & 1.309 & 1.192 & 1.464 & 1.452 & 1.449 & 0.798 & 2.365 \\
\hline
\end{tabular}

$*=$ Negative control, $* *=$ Positive control

\section{Sensitivity of the newly developed In-House sandwich ELISA}

The known IBD virus dilution, $10^{-3}$ appeared to be the highest dilution, which had the lowest capacity to bind with the coated antibody of the ELISA plate (Table 2). This result indicated that IBD viruses absent in the dilution which was above $10^{-3}$ resulting that they failed to bind with the coated antibody of the ELISA plate which agree with the earlier report of Barman et al. (2003). The column 11 containing negative control serum did not show any binding where as, the column 12 showed type specific binding with positive control serum.

Table 2: OD values of the results of sensitivity of newly developed in-House sandwich ELISA.

\begin{tabular}{|c|c|c|c|c|c|c|c|c|c|c|c|c|c|c|}
\hline & \multirow[b]{2}{*}{$\begin{array}{l}\text { Dilution of } \\
\text { hyper- } \\
\text { immune } \\
\text { serum for } \\
\text { coating of } \\
\text { the plate }\end{array}$} & \multirow[b]{2}{*}{ 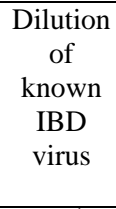 } & \multicolumn{12}{|c|}{ OD value of sandwich ELISA } \\
\hline & & & 1 & 2 & 3 & 4 & 5 & 6 & 7 & 8 & 9 & 10 & $11^{*}$ & $12^{* * *}$ \\
\hline A & $10^{-2}$ & $10^{-1}$ & 2.598 & 2.586 & 2.497 & 2.486 & 2.473 & 2.435 & 2.558 & 2.531 & 2.564 & 2.537 & 0.598 & 2.169 \\
\hline B & $10^{-2}$ & $10^{-1}$ & 2.561 & 2.581 & 2.565 & 2.561 & 2.536 & 2.496 & 2.483 & 2.538 & 2.567 & 2.546 & 0.637 & 2.198 \\
\hline C & $10^{-2}$ & $10^{-2}$ & 2.475 & 2.469 & 2.547 & 2.434 & 2.416 & 2.402 & 2.461 & 2.438 & 2.443 & 2.436 & 0.689 & 2.276 \\
\hline $\mathrm{D}$ & $10^{-2}$ & $10^{-2}$ & 2.432 & 2.416 & 2.401 & 2.494 & 2.479 & 2.445 & 2.423 & 2.505 & 2.473 & 2.501 & 0.765 & 2.265 \\
\hline $\mathrm{E}$ & $10^{-2}$ & $10^{-3}$ & 1.548 & 1.596 & 1.653 & 1.587 & 1.584 & 1.579 & 1.616 & 1.608 & 1.616 & 1.568 & 0.628 & 2.258 \\
\hline $\mathrm{F}$ & $10^{-2}$ & $10^{-3}$ & 1.596 & 1.612 & 1.598 & 1.584 & 1.593 & 1.595 & 1.539 & 1.601 & 1.565 & 1.623 & 0.773 & 2.349 \\
\hline G & $10^{-2}$ & $10^{-4}$ & 0.781 & 0. & 34 & 0.673 & 0.679 & 0.614 & 0.661 & 0.589 & 0.568 & 0.713 & 0.783 & 2.456 \\
\hline $\mathrm{H}$ & $10^{-2}$ & $10^{-4}$ & 0.578 & 0.627 & 0.583 & 0.617 & 0.698 & 0.609 & 0.671 & 0.576 & 0.768 & 0.715 & 0.791 & 2.537 \\
\hline
\end{tabular}

$*$ = Negative control, **= Positive control 


\section{Determination of cut-off value from negative control readings}

The cut-off value of present ELISA system was determined by using the mean absorbance of negative control (Table 1 \& 2) plus three times the standard deviation (Kumar \& Rao, 1991). The cut-off value of present ELISA system is calculated as 0.940 (Table 3). If the titer of tested samples with the newly developed In-House sandwich ELISA is greater than 0.940, indicates IBDV positive whereas, less than 0.940 indicates negative.

Calculation Factor: Cut-off Value $=($ Mean $\pm 3 \times$ standard deviation $)$ of the negative control serum.

Table 3: Cut-off value for newly developed In-House sandwich ELISA

\begin{tabular}{|c|c|c|c|c|}
\hline Serial no & OD value & Mean \pm SD & Mean+3SD & Cut-off value \\
\hline 1 & 0.639 & & & \\
\hline 2 & 0.568 & & & \\
\hline 3 & 0.697 & & & \\
\hline 4 & 0.772 & & & \\
\hline 5 & 0.695 & & & \\
\hline 6 & 0.624 & & & \\
\hline 7 & 0.786 & & & \\
\hline 8 & 0.798 & & & \\
\hline 9 & 0.598 & $0.703 \pm 0.079$ & $0.703 \pm 0.237$ & 0.940 \\
\hline 10 & 0.637 & & & \\
\hline 11 & 0.689 & & & \\
\hline 12 & 0.765 & & & \\
\hline 13 & 0.628 & & & \\
\hline 14 & 0.773 & & & \\
\hline 15 & 0.783 & & & \\
\hline 16 & 0.791 & & & \\
\hline
\end{tabular}

Specificity of the newly developed In-House sandwich ELISA by using known IBD and ND viruses

The IBD virus was found to bind with the coated antibody instead of ND virus in the plate, which revealed the high specificity of the newly developed In-House sandwich ELISA against IBD (Table 4).

Table 4. OD values of the result of specificity of newly developed in-House sandwich ELISA

\begin{tabular}{|c|c|c|c|c|c|c|c|c|c|c|c|c|c|c|}
\hline \multirow{2}{*}{\multicolumn{2}{|c|}{$\begin{array}{c}\text { Hyper- } \\
\text { immune } \\
\text { serum } \\
\text { dilution to } \\
\text { coat the } \\
\text { plate }\end{array}$}} & \multirow{2}{*}{$\begin{array}{c}\text { Dilution of } \\
\text { known ND } \\
\& \text { IBD } \\
\text { viruses }\end{array}$} & \multicolumn{12}{|c|}{ OD value of different dilution of ND and IBD viruses } \\
\hline & & & 1 & 2 & 3 & 4 & 5 & 6 & 7 & 8 & 9 & 10 & $11^{*}$ & $12^{* *}$ \\
\hline A & $10^{-2}$ & $10^{-1}(\mathrm{IBD})$ & 2.659 & 2.647 & 2.629 & 2.698 & 2.684 & 2.753 & 2.661 & 2.685 & 2.653 & 2.647 & 0.647 & 2.173 \\
\hline B & $10^{-2}$ & $10^{-1}(\mathrm{ND})$ & 0.556 & 0.528 & 0.564 & 0.543 & 0.527 & 0.545 & 0.561 & 0.532 & 0.554 & 0.516 & 0.505 & 2.189 \\
\hline C & $10^{-2}$ & $10^{-2}$ (IBD) & 2.413 & 2.494 & 2.461 & 2.512 & 2.497 & 2.445 & 2.443 & 2.513 & 2.456 & 2.501 & 0.758 & 2.267 \\
\hline D & $10^{-2}$ & $10^{-2}(\mathrm{ND})$ & 0.664 & 0.613 & 0.681 & 0.618 & 0.521 & 0.615 & 0.582 & 0.528 & 0.613 & 0.548 & 0.701 & 2...246 \\
\hline E & $10^{-2}$ & $10^{-3}$ (IBD) & 1.693 & 1.638 & 1.614 & 1.598 & 1.657 & 1.601 & 1.643 & 1.576 & 1.563 & 1.511 & 0.607 & 2.348 \\
\hline$F$ & $10^{-2}$ & $10^{-3}(\mathrm{ND})$ & 0.769 & 0.758 & 0.689 & 0.696 & 0.615 & 0.569 & 0.583 & 0.561 & 0.572 & 0.531 & 0.554 & 2.469 \\
\hline G & $10^{-2}$ & $10^{-4}(\mathrm{IBD})$ & 1.501 & 1.568 & 1.593 & 1.558 & 1.521 & 1.538 & 1.614 & 1.589 & 1.567 & 1.576 & 0.782 & 2.563 \\
\hline $\mathrm{H}$ & $10^{-2}$ & $10^{-4}(\mathrm{ND})$ & 0.781 & 0.726 & 0.686 & 0.649 & 0.596 & 0.674 & 0.661 & 0.567 & 0.572 & 0.512 & 0.662 & 2.581 \\
\hline
\end{tabular}

$*=$ Negative control, $* *=$ Positive control 


\section{Determination of sensitivity and specificity of in-house sandwich ELISA}

\section{Evaluation of sensitivity and specificity of newly developed In-House sandwich ELISA for the diagnosis of field samples}

In case of experimental infection, 5 (62.5\%) of 8 fecal samples and none of the cloacal swab samples were positive for IBDV by newly developed In-House sandwich ELISA assay. The fecal samples collected after day 2 to 4 of post infection was positive for the detection of virus and was absent in the sample of day first of infection. Both the bursa and spleen of experimentally infected dead birds were positive for the diagnosis of IBD (Table 5 \& 7). The result partially supports the findings of Kanani (2000).

In case of natural outbreak cases in the layer farms of Muktagach, Sirajgonj and Mymensingh areas, 6 (100\%) of 6 bursal samples and 4 (66.66\%) of 6 spleen samples were positive for the diagnosis of IBD. Spleen sample of each bird of Sirajgonj and Mymensingh district was negative for IBDV (Table 6 \& 8).

Table 5. OD values of the test samples of experimentally infected group of bird

\begin{tabular}{|c|c|c|c|c|c|c|c|c|c|c|c|c|c|}
\hline & \multirow{3}{*}{$\begin{array}{c}\text { Sample } \\
\text { description }\end{array}$} & \multicolumn{12}{|c|}{ OD value of sandwich ELISA } \\
\hline & & 1 & 2 & 3 & 4 & 5 & 6 & 7 & 8 & 9 & 10 & 11 & 12 \\
\hline & & \multicolumn{6}{|c|}{ Feces sample } & \multicolumn{6}{|c|}{ Cloacal sample } \\
\hline A & Day 1 & 0.714 & 0.726 & 0.665 & 0.701 & 0.711 & 0.698 & 0.679 & 0.765 & 0.723 & 0.709 & 0.679 & 0.598 \\
\hline B & Day 2 & 2.797 & 2.815 & 2.896 & 2.869 & 2.856 & 2.745 & 0.621 & 0.693 & 0.764 & 0.768 & 0.676 & 0.667 \\
\hline C & Day 3 & 2.839 & 2.853 & 2.814 & 2.832 & 2.783 & 2.616 & 0.824 & 0.736 & 0.746 & 0.597 & 0.539 & 0.648 \\
\hline $\mathrm{D}$ & Day 4 & 2.867 & 2.851 & 2.845 & 2.783 & 2.869 & 2.589 & 0.865 & 0.798 & 0.711 & 0.756 & 0.765 & 0.636 \\
\hline \multirow[t]{2}{*}{$\mathrm{E}$} & Control & 0.656 & 0.723 & 0.712 & 0.665 & 0.663 & 0.598 & 0.701 & 0.645 & 0.543 & 0.653 & 0.789 & 2.269 \\
\hline & & \multicolumn{6}{|c|}{ Bursal samples } & \multicolumn{6}{|c|}{ Spleen } \\
\hline $\mathrm{F}$ & Dead birds & 2.756 & 2.769 & 2.813 & 2.746 & 2.778 & 2.801 & 2.815 & 2.798 & 2.764 & 2.758 & 2.637 & 2.223 \\
\hline $\mathrm{G}$ & Control & 0.742 & 0.563 & 0.495 & 0.521 & 0.563 & 0.498 & 0.475 & 0.421 & 0.391 & 0.403 & 0.567 & 0.456 \\
\hline $\mathrm{H}$ & Blank & BL & BL & BL & BL & BL & BL & BL & BL & BL & BL & 0.783 & 2.465 \\
\hline
\end{tabular}

Table 6. OD values of the samples from natural outbreak cases

\begin{tabular}{clcccccccccccc}
\hline & \multirow{2}{*}{ Sample description } & \multicolumn{10}{c}{ OD value of different dilution of IBD virus } \\
\cline { 2 - 13 } & 1 & 2 & 3 & 4 & 5 & 6 & 7 & 8 & 9 & 10 & 11 & 12 \\
\hline $\mathrm{A}$ & Bursa (Sirajgonj) & 2.768 & 2.776 & 2.713 & 2.745 & 2.764 & 2.756 & 2.189 & 2.789 & 2.636 & 2.713 & 2.786 & 2.169 \\
$\mathrm{~B}$ & Spleen (Sirajgonj) & 2.745 & 2.789 & 2.506 & 2.896 & 2.856 & 2.895 & 0.881 & 0.874 & 0.835 & 0.736 & 0.702 & 0.798 \\
$\mathrm{C}$ & $\begin{array}{l}\text { Bursa } \\
\text { (Mymensingh) }\end{array}$ & 2.738 & 2.856 & 2.858 & 2.865 & 2.835 & 2.619 & 2.876 & 2.859 & 2.765 & 2.739 & 2.689 & 2.213 \\
$\mathrm{D}$ & $\begin{array}{l}\text { Spleen } \\
\text { (Mymensingh) }\end{array}$ & 2.912 & 2.869 & 2.764 & 0.781 & 2.765 & 2.732 & 0.764 & 0.778 & 0.637 & 0.864 & 0.765 & 0.665 \\
$\mathrm{E}$ & $\begin{array}{l}\text { Bursa } \\
\text { (Muktagacha) }\end{array}$ & 2.902 & 2.754 & 2.812 & 2.896 & 2.873 & 2.737 & 2.756 & 2.868 & 2.832 & 2.731 & 2.732 & 2.198 \\
$\mathrm{~F}$ & $\begin{array}{l}\text { Spleen } \\
\text { (Muktagacha) }\end{array}$ & 2.712 & 2.598 & 2.543 & 2.832 & 2.843 & 1.776 & 1.785 & 1.736 & 1.813 & 1.636 & 2.698 & 2.256 \\
$\mathrm{G}$ & $\begin{array}{l}\text { Blank } \\
\mathrm{H}\end{array}$ & $\mathrm{BL}$ & $\mathrm{BL}$ & $\mathrm{BL}$ & $\mathrm{BL}$ & $\mathrm{BL}$ & $\mathrm{BL}$ & $\mathrm{BL}$ & $\mathrm{BL}$ & $\mathrm{BL}$ & $\mathrm{BL}$ & $\mathrm{BL}$ & $\mathrm{BL}$ \\
\hline
\end{tabular}

Sensitivity and specificity of AGIDT to diagnose clinical and post-mortem samples of experimentally and naturally infected chickens

AGID has been reported by a number of workers to be useful in easy screening of the field samples, prior to either isolation or detection and characterization of the virus (Parthiban et al., 2000 and Kadam, 2001). In case of experimental infection, 5 (62.5\%) of 8 fecal samples but no cloacal swab samples and all the postmortem samples (2 bursa and 2 spleen) were positive by AGIDT (Table 7). The positive fecal samples were collected within day 2 to 4 of post infection and sample of first day was negative. The result correspond with the findings of Dash et al. (1991) and Kanani, (2000) who detected IBDV antigen in BF from one to sixth day of PI using AGIDT. Among the 12 post mortem samples ( 6 bursa +6 spleens) of natural outbreaks, all the bursal samples 
(100\%) but 3 spleen samples (50\%) revealed distinct white line of precipitation with anti-chicken/rabbit serum against IBDV (Table 8). The result is in good agreement with the findings of Prajapati and Jalnapurkar (1982), Panisup et al. (1989), Snyder et al. (1992), Vijaya Praveen et al. (1995) and Parthiban et al. (2001).

Table 7. IBDV positive cases by developed In-House sandwich ELISA and AGIDT from the samples of experimentally infected cases

\begin{tabular}{|c|c|c|c|c|c|}
\hline \multirow{2}{*}{$\begin{array}{l}\text { Experimental } \\
\text { infection }\end{array}$} & \multirow{2}{*}{$\begin{array}{l}\text { No. of } \\
\text { birds }\end{array}$} & \multirow{2}{*}{ Type of samples } & \multirow{2}{*}{$\begin{array}{c}\text { No. of } \\
\text { samples } \\
\text { tested }\end{array}$} & \multicolumn{2}{|c|}{ No. of IBDV Positive samples } \\
\hline & & & & In-House ELISA & AGIDT \\
\hline \multirow{2}{*}{ Day-1 } & \multirow[b]{2}{*}{2} & Feces & 2 & 0 & 0 \\
\hline & & Cloacal swab & 2 & 0 & 0 \\
\hline \multirow{2}{*}{ Day-2 (Sick) } & \multirow[b]{2}{*}{2} & Feces & 2 & 1 & 1 \\
\hline & & Cloacal swab & 2 & 0 & 0 \\
\hline \multirow{2}{*}{ Day-3 (Sick) } & \multirow{3}{*}{2} & Feces & 2 & 2 & 2 \\
\hline & & Cloacal swab & 2 & 0 & 0 \\
\hline \multirow{4}{*}{ Day-4 (Dead) } & & Feces & 2 & 2 & 2 \\
\hline & \multirow{3}{*}{2} & Cloacal swab & 2 & 0 & 0 \\
\hline & & Bursa & 2 & 2 & 2 \\
\hline & & Spleen & 2 & 2 & 2 \\
\hline \multirow{4}{*}{ Control (Dead) } & \multirow{4}{*}{1} & Faeces & 1 & 0 & 0 \\
\hline & & Cloacal swab & 1 & 0 & 0 \\
\hline & & Bursa & 1 & 0 & 0 \\
\hline & & Spleen & 1 & 0 & 0 \\
\hline
\end{tabular}

Table 8. IBDV positive cases by developed In-House sandwich ELISA and AGIDT from the samples of naturally infected cases

\begin{tabular}{|c|c|c|c|c|c|}
\hline \multirow{2}{*}{ Places of sampling } & \multirow{2}{*}{$\begin{array}{l}\text { No. of dead } \\
\text { birds }\end{array}$} & \multirow{2}{*}{$\begin{array}{l}\text { Type of } \\
\text { samples }\end{array}$} & \multirow{2}{*}{$\begin{array}{c}\text { No. of } \\
\text { samples } \\
\text { tested } \\
\end{array}$} & \multicolumn{2}{|c|}{ No. of IBDV Positive samples } \\
\hline & & & & In-House ELISA & AGIDT \\
\hline \multirow{2}{*}{ Sirajgonj } & \multirow{2}{*}{2} & Bursa & 2 & 2 & 2 \\
\hline & & Spleen & 2 & 1 & 1 \\
\hline \multirow[t]{2}{*}{ Mymensingh } & \multirow{2}{*}{2} & Bursa & 2 & 2 & 2 \\
\hline & & Spleen & 2 & 1 & 1 \\
\hline \multirow{2}{*}{ Muktagacha } & \multirow{2}{*}{2} & Bursa & 2 & 2 & 2 \\
\hline & & Spleen & 2 & 2 & 1 \\
\hline
\end{tabular}

Comparison between newly developed In-House sandwich ELISA and Agar gel immunodiffusion test (AGIDT)

The result of AGIDT from different experimental IBDV infection using known hyper-immune serum against IBDV showed $100 \%$ similarity with the results of newly developed In-House sandwich ELISA (Table 7). In case of natural outbreak, the result was almost similar except one splenic sample of Muktagacha which was negative by AGIDT but was positive by In-House sandwich ELISA (Table 8). The result was correspondent with the findings of Ajinkya et al. (1980) who reported that bursal suspensions were more reliable source for IBDV antigen. Out of total 32 tested samples except control, 19 (9 experimental infection and 10 natural outbreak) were 
positive for IBDV by newly developed In-House sandwich ELISA whereas, 18 (9 experimental infection and 9 natural outbreak) by AGIDT which revealed 92.85\% specificity of newly developed In-House sandwich ELISA method with AGIDT (Table 9).

Table 9. Results of specificity test

\begin{tabular}{llllll}
\hline & & $\begin{array}{l}\text { Gold standard } \\
\text { immunodiffusion test) }\end{array}$ & (agar & gel & Total \\
\cline { 3 - 5 } & & Positive & Negative & \\
\cline { 3 - 5 } In-House sandwich & Positive & 18 & 1 & 19 \\
ELISA & Negative & 0 & 13 & 13 \\
Total & & 18 & 14 & 32 \\
Specificity $(\mathrm{d} / \mathrm{b}+\mathrm{d} \times \mathrm{100})$ & & & $92.85 \%$ \\
\hline
\end{tabular}

From the above findings the present study may be concluded that studies of the molecular epidemiology of IBDV are important and the In-House sandwich ELISA could be used as an alternative technique for screening a large number of samples before testing (Tham et al., 1995) and also for the confirmation of the IBDV quickly from a large number of IBD suspected field samples. If it is produced commercially in a country it can be a valuable tool for the detection of IBDV virus with minimum cost and it is highly reliable like other procedures of IBDV isolation and detection such as AGIDT, molecular detection.

\section{REFERENCES}

1. Ajinkya SM, Survashe BD and Sardeshpande PD (1980). Breakdown in immunity to Ranikhet disease (Newcastle disease) with infectious bursal disease (Gumboro disease) in broiler chicks. Indian Veterinary Journal 57: 265-269.

2. Banda A (2002). Characterization of field strains of Infectious bursal disease virus (IBDV) using molecular techniques. Dissertation (Doctor of Pholosophy).

3. Barman NN, Roychoudhury P and Dutta TC (2003). Double antibody sandwich ELISA for detection of infectious bursal disease virus. Indian Veterinary Journal 80 (12): 1209-1211

4. Cosgrove AS (1962). An apparently new disease of chickens- avian nephrosis. Avian Diseases 6: 385-389.

5. Dash BB, Verma KC and Kataria JM (1991). Comparison of some serological tests for detection of IBD virus infection in chicken. Indian Journal of Poultry Science 26: 160-165.

6. Howie RI and Thorson J (1981). An enzyme-linked immunosorbent assay (ELISA) for infectious bursal disease virus (IBDV). Canadian Journal of Comparative Medicine 45:315-320.

7. Jackwood DJ, Saif YM and Hughes JH (1984). Nucleic acid and structural proteins of infectious bursal disease virus isolates belonging to serotypes I and II. Avian Diseases 28: 990-1006.

8. Joshi RK and Shakya S (1996). Studies on an infectious bursal disease outbreak in a commercial poultry farm in Madhya Pradesh. Indian Veterinary Medicine Journal 20: 41-42.

9. Kadam M (2001). Disease resistance pattern and virus detection studies on infectious bursal disease in different breeds of experimentally infected chicken. M.V.Sc. Thesis, Gujarat Agricultural University, Sardar Krushinagar.

10. Kanani A (2000). Pathological, immunosuppression and virus detection studies on infectious bursal disease in experimentally infected chicken. M.V.Sc. Thesis, Gujarat Agricultural University, Sardar Krushnagar.

11. Kumar A and Rao AT (1991). Double-antibody sandwich elisa for detection of infectious bursal disease virus. British Veterinary Journal 147: 251-255.

12. Liu X, Giambrone JJ and Dormitorio T (1998). Simplified sample processing combined with a sensitive nested polymerase chain reaction assay for detection of infectious bursal disease virus in the bursa of Fabricus. Avian Diseases 42: 480-485.

13. Makadiya NR (2004). Detection of infectious bursal disease virus from bursal tissue by RT-PCR and its comparative efficacy with conventional precipitation assays. M.V.Sc. Thesis, Anand Agricultural University, Anand. 


\section{P K Saha and others}

14. Marquardt WW, Johnoson RB, Odenwald WF and Schlottober BA (1980). An indirect enzyme-linked immunosorbent assay (ELISA) for measuring antibodies in chickens infected with infectious bursal disease virus. Avian Diseases 24: 375-385.

15. McFerran JB, McNulty MS, McKillip ER, Conner TJ, McCrauken RM, Collins DS and Allam GM (1980). Isolation and serological studies of IBDV from fowl, turkey and ducks: demonstration of second serotype. Avian Pathology 9: 395-405.

16. Panisup AS, Verma KC, Kataria JM and Mohanty GC (1989). Studies on the response of chicks to field isolates and a vaccine strain of IBD. Indian Journal of Poultry Science 24: 210-215.

17. Parthiban M, Sujatha TD, Thiagarajan V and Velmurugan R (2001). Optimization of polymerase chain reaction for detection of infectious bursal disease virus. Indian Journal of Animal Research 35: 132-134.

18. Patnayak DP, Kalra SK, Arvind K and Maherchandani S (1997). Indian Journal of Virology 13: 69-72.

19. Prajapati KS and Jalnapurkar BV (1982). Studies on natural outbreaks of IBD in chickens. Gujarat Agril. Univ. Research. Journal 7: 110-112.

20. Samad A, Awaz KB and Sarkate LB (1994). Diagnosis of bovine traumatic reticulo peritonitis I: strength of clinical signs in predicting correct diagnosis. Journal of Applied Animal Research 6: 13-18.

21. Solano W, Giamborone JJ and Pananga VS (1986). Comparison of a kinetic-based enzyme-linked immunosorbent assay (KELISA) and virus-neutralization test for infectious bursal disease virus. I. Quantitation of antibody in white legnhorn hens. Avian Diseases 29: 662-671.

22. Tanimura N, Tsukamoto K, Nakamura K, Narita M \& Maeda M (1995). Association between pathogenicity of infectious bursal disease virus and viral antigen distribution detected by immunohistochemistry. Avian Diseases 39: 9-20.

23. Tham KM, Young LM \& Moon CD (1995). Detection of infectious bursal disease virus by reverse transcription polymerase chain reaction amplification of the virus segment A gene. Journal of Virological Methods 53: 201-212.

24. Thevathasan C and Jayawardana GWL (1997). Studies on infectious bursal disease virus isolated from field outbreaks. Tropical Agrilcultural Research 9: 372-377.

25. Umapathi V, Parthiban M, Thiagarajan V and Nachimuthu K (2002). Preparation and characterization of immunogen for monoclonal antibody production against infectious bursal disease virus serotype 1 of poultry. Journal of Immunology and Immunopathology 4: 113-116.

26. Van den Berg TP, Gonze M, Morales D and Meulemans G (1991). Acute infectious bursal disease in poultry, isolation and characterization of a highly virulent strain. Avian Pathology 20: 133-143.

27. Vijaya Praveen K, Rao SA and Chetty MS (1995). Isolation, identification and characterization of infectious bursal disease virus in Andhra Pradesh. Indian Veterinary Journal 72: 5-9.

28. Wyeth PJ (2000). Infectious bursal disease (Gumboro disease). In: manual of standards for diagnostics tests and vaccines, 4th Ed. Office International Des Epizooties, Paris, France, pp. 647-656. 